\title{
The New Albanian Company Law a Serious Effort for the Implementation of Europian Standards of Law on Commercial Company
}

\author{
Valbona Shukarasi \\ Phd.Candidate, Private Law
}

Abstract

\begin{abstract}
Albanian Company law has changed profoundly in recent time. These changes have not merely been limited to technical issues, but amount to a revolution in core areas of the Albanian company law framework. To a large extent, these changes were driven by the Stabilisation and Association Agreement between Albanian and The European Union, aiming inter alia at the approximation of Albania's existing legislation to the Community acquis. ${ }^{1}$ Given the objective to bring Albanian law in line with European Union requirements on company law, it is not a big surprise that the legislator assisted by international experts essentially decided to design a new company law "from scratch" rather than modifying the existing Albanian legal framework. After all, the peviously on companies followed a very different approach than most of the Member States'systems which served as the basis for the Community legislation in this area. Rewriting a whole company law system undoubtedly is a very ambitious task, as each country's legal and economic environment has its very own specifics; additionally, company law always interects intensively with different areas of legislation (e.g. accounting, tax and securities laws). This paiper will focus in three main points: The Compani as a Separate Legal Person - General Consideration; The Act's Europian and Comperative Origins; Types of Companies; The Scope of Application of the $\mathrm{ACL}^{2}$ - the case law of the judicial practice of the European Court of Justice.
\end{abstract}

Keywords: New Albanian Company Law, Serious Effort, Implementation, Europian Standards of Law on Commercial Company

\section{The Company as a separate Legal Person}

One important feature of company law is the acknowledgement of the company as separate legal person distinct from its members or shareholders. Conferring legal personality onto dhe company enables the company to have rights and duties in relation to third parties and in relation to its members. Moreover, court proceedings may be brought by the company (as plaintiff) or against the company (as defandant).

In particular, the company's status as a legal person allows the company to own property and be entered in a register of ownership (e.g. land register; commercial register if the company owns shares in another company of the LLC (limited liability company) type; share registry pursuant to Art $119 \mathrm{ACL}$ if the company owns shares in another company of the JSC (joint stock company) type. Assets belonging to the company are in law owned by company only, not by its shareholders. This is true even if the company is a single-member company (Art 3 (1) ACL). Correspondingly, owning a share in the company does not mean owning a share in the company's assets.

Legal persons are artificial creatures of the law. If we ask why dhe law creates them, perhaps the primary answer is the simplification of legal relations. While the concept of legal person is much older (it was first developed in mediaval times in relation to religious institutions), the idea of assigning the status of a legal person to (commercial) companies is mainly a consequence of economic developments in the 19th century, when more and more companies raised large amounts of capital to invest in infrastructure projects (e.g.railway lines). The only alternative to separate legal personality for the company would have been to treat each member of the company as the legal subject of the rights and duties arising from the bussines, which is clearly impractical if the company has a large number of shareholders. Moreover, separate legal personality allows for change in the company's membership (e.g. by the transfer of shares i a JSC) without a direct effect on the company's legal relationships with third parties. Declaring commercial companies to be legal persons greatly simplifies the legal handling of a more and more complex business environment.

\footnotetext{
${ }^{1}$ Secondary Legislation - refers to the total legislation applicable to EC Member States including the legal framework that shall adopt a country to become part of the European Union.

${ }^{2}$ In this paper the new law will be cited as "Companies Law" (abbreviated to ACL).
} 
But the existence of companies as separate legal persons soon developed its own dinamics and created at least two new problems. Initially, many company laws did not permit companies to own shares in another company; only natural persons could be members or shareholders.

Secondly, entrepreneurs with small businesses soon discovered seperate legal personality as a way to run their business with the benefit of limited liability. Legal rules requiring a minimum member of founders ${ }^{1}$ could be circumvented with the help of straw men, who would transfer their shares to the entrepreneur immediately after registration. Some company laws reacted by taking away limited liability if a company had only one member or shareholder. However, the Twelfth Company Law Directive ${ }^{2}$ now requires all Member States to permit single-member companies of the LLC type. Under Albanian law, a LLC as well as a JSC may be formed by one person only (Art 3 (1) ACL).

Given the artificial nature of a legal person, it does not have a human will. The company is a tool in the hands of the people who control it, either by acting as organs of the company or by exercising a decisive influence on those who act as organs (and, therefore, on behalf of the company). This tool may be utilised for legitimate purposes, but it may also be abused for illegimated purposes. Art $16 \mathrm{ACL}$ is one attempt to counteract such abuse. The provision renders members or shareholders of the company as well as administrators personally liable for the obligations of the company.

\section{The Act's Europian and Comperative Origins.}

The ACL's rules do not continue the traditions under dhe former legal regime under the Law No.7638 (the old Law), but revolutionise Albania's company law. There is little or no continuity between the old law and the new.

The Albanian Company Law was drafted so as to implement (with limited exceptions) the Europian company law standards (the so called "acquis") and thereby to fulfil Art 70 of the Stabilisation and Association Agreement between Albania and the Europian Union, which aims at full approximation to the acquis communautaire.

As it has been the aim of legislator to implement European law, provisions of the Companies Law which are derived from a Europian source should be interpreted according to the "word and spirit" of the relevant European harmonisation measure. However, this is not possible where it is obvious that the Albanian provision clearly and intentionally deviates from the Europen provision, as we shall point out in the relevant contexts.

However, it has to be noted that there is no coherent body European company law. Rather, European Directives focus on the joint-stock company and contain only few rules on limited liability companies and almost none on partnerships. And even for the joint-stock company European law treats only certain topics, e.g. the provisions on capital and the distribution of dividends, but contains little rules on others, e.g. the management of the company or corporate governance issues. Therefore, National Company Laws in the Europian Union differ widely in many aspects and the Albanian legislator enjoyed considerable leeway when drafting the new Companies Law.

For matters not regulated by Europian Law, the new Albanian Companies Law relies heavily on inspiration from the company laws of Germany and England. Accordingly, guidance on the interpretation of the law may also come from the courts of a Member State if the provision in question was taken from the corresponding Member State Law.

Therefore, the following provide guidance for interpreting the Albanian Company Law:

(i) the relevant EU Directives;

(ii) Commentary of the new Companies Law; ${ }^{3}$

(iii) doctrine and jurisprudence on rules in other jurisdictions, especially Germany and

England if a certain provision in the ACL is clearly based on such a rule.

\footnotetext{
1 Such rules aimed at restricting the benefits of separate legal personality and limited liability to circumtamces as described above.

2 Twelfth Council Company Law Directive 89/667/EEC of 21 December 1989 on single-member private limited-liability companies, OJ L $395,30.12 .1989$, p.40-42.

${ }^{3}$ The New Law "On Entrepreneurs and Companies" - Text with Commentary
} 


\section{Types of Companies}

Types of Companies - The new law No.9901 on Entrepreneurs and Companies regulates four types of bussines organisation referred to by the generic term "commercial company" namely :
the general partnership,
the limited partnership,
the limited liability company
the joint-stock company

Very broadly speaking these four types correspond to the following types of business organisation found in the other Europian jurisdictions.

\begin{tabular}{|c|c|c|c|c|}
\hline Albania & Italy & France & Germany & England \\
\hline $\begin{array}{l}\text { shoqeri } \\
\text { kolektive }\end{array}$ & $\begin{array}{l}\text { società in } \\
\text { nome collettivo }\end{array}$ & $\begin{array}{l}\text { société en } \\
\text { nom collectif }\end{array}$ & $\begin{array}{l}\text { Offene } \\
\text { handelsgesellschaft }\end{array}$ & $\begin{array}{l}\text { (general) } \\
\text { partnership }\end{array}$ \\
\hline $\begin{array}{l}\text { shoqeri } \\
\text { komandite }\end{array}$ & $\begin{array}{l}\text { società in } \\
\text { accomandita } \\
\text { semplice }\end{array}$ & $\begin{array}{l}\text { société en } \\
\text { commandite } \\
\text { simple }\end{array}$ & $\begin{array}{l}\text { Kommandit } \\
\text { gesellschaft }\end{array}$ & limited partnership \\
\hline $\begin{array}{l}\text { shoqeri me } \\
\text { pergjegjesi te } \\
\text { kufizuara }\end{array}$ & $\begin{array}{l}\text { società a } \\
\text { resposabilitá } \\
\text { limitata }\end{array}$ & $\begin{array}{l}\text { société á } \\
\text { responsabilité } \\
\text { limitée }\end{array}$ & $\begin{array}{l}\text { Gesellschaft mit } \\
\text { Beschränkter } \\
\text { haftung }\end{array}$ & $\begin{array}{l}\text { private company } \\
\text { limited } \\
\text { by shares }\end{array}$ \\
\hline shoqeri aksionere & $\begin{array}{l}\text { società per } \\
\text { azioni }\end{array}$ & $\begin{array}{l}\text { Société } \\
\text { anonyme }\end{array}$ & Aktiengesellschaft & $\begin{array}{l}\text { public company } \\
\text { limited by } \\
\text { shares }\end{array}$ \\
\hline
\end{tabular}

As can be seen from this table, the Albanian word "shoqëri" correspond to the Italian "società", the French "société" and the German "Gesellschaft", whereas, in legal parlance, the English word "company" is normally used in a narrower sense and does not include partnerships. ${ }^{1}$ Moreover, under English law, only companies, not partnerships have the status of a legal person, whereas the Albanian law - in line with French law and with the previous Law No.76382 - confers the status of a legal person to all types of bussines entities regulated in the Companies Law. ${ }^{3}$

At the first sight the distinction between partnerships and companies appears to reflect the distinction between "società di persone" / "sociétés de personnes", on the hand, and "società di capitali" / "sociétés de capitaux", on other hand, although one should be very careful with these classifications. Looking through Italian and French textbooks, one realises that there is no general agreement on where to draw the line between the to categories. The classic borderline case is the "società a responsabilitá limitata" / "société

\footnotetext{
${ }^{1}$ The distinction is made explicit in Art 3 of the Model Companies Law ( Janet Dine/Marios Koutsias/ Michael Blecher, Company Law in the New Europe, 2007, pp 145 et seqq; henceforth cited as "MCL"), but was not taken over in the "official" English version of the Albanian Companies Law.

${ }^{2}$ And in accordance with Art 3(2) MCL.

${ }^{3}$ Art 3 (3) ACL "A company shall acquire legal personality on the date of its registration with the National Registration Centre. It shall be liable with all its assets for the obligations deriving from its activities".
} 
responsabilité limitée", which, depending on the Statute given to it by its members, may take on a highly personalised character in some regards, but nevertheless shares common features with the "società per azioni" / "société anonyme" in other regards. The ACL does not build on this categorisation.

\section{The Scope of Application of the ACL - the case law of the judicial practice of the European Court of Justice.}

Every national system of company law must have rules to determine its scope of application in cases where there is a cross-border situation (internationa company law). Broadly speaking, legal system follow ome of the two possible solutions. The first solution emphasises the freedom of choice for company founders and allows them to incorporate their company in a jurisdiction even though the company has no economic links with that jurisdiction; this solution may result in so-called "letter-box" companies, whose "prezence" in the urisdiction of incorporation consist of no more than a postal address (e.g. in the office of a lawyer), whereas all its business is conducted in one or more other jurisdictions. Still, the company is governed by the company law of its jurisdiction of icorporatio, hence this rule of internationale company law is known as the "incorporation theory". The second solution denies this freedom of choice for company founders and determines dhe law governing the company with reference to an objective factor, namely the location of the company's head office or "real seat" hence this rule of international company law is known as the "real seat theory".

In Albania, the relevant provision is Art $8 \mathrm{ACL}$, and, according to the Commentary, this provision is meant to follow the real seat doctrine. ${ }^{1}$ Indeed, Art 8 (2) ACL states that a company is subject to the provisions of ACL if its head office is located in the territory of Republic of Albania. ${ }^{2}$

However, the intriguing part of Art 8 ACLis its the first paragraph, which provides that a company's head office is the place

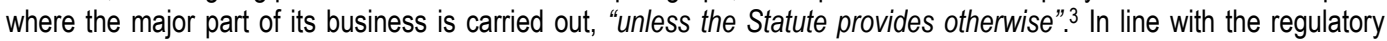
purpose of he real seat theory, which is to deny the founders a choice of the aplicable law for their company, one would expect the definition of head office to apply without proviso that the Statute may "provide otherwise". By contrast, Art 8(1) ACL appears to give dhe Statute the freedom to define any place as the company's head office, irrespective of whether the company has any operations in this place. If this liberty for the Statute to define any place as the company's head office also has effect for the purposes of Art 8 (2) ACL, this would, in effect, allow for precisely the choice of the applicable law permitted by the incorporation theory. Given the Art $8 \mathrm{ACL}$ depart from the model provision in Art $6 \mathrm{MCL}$ (which is clearly an instance of the real seat theory), conclude that Art $8 \mathrm{ACL}$ has introduced the incorporation theory into Albanian law.

\subsection{ECJ Case Law on Freedom of Establishment - Cross-border Mobility}

Looking at the company law Directives adopted util 1989, it becomes abvious that the programme of secondary legislation based on Article $54(3)(\mathrm{g})$ of the EC-Treaty was preoccupied with approximation of national company laws in the sense of creating uiform legal rules even in purely domestic situations. ${ }^{4}$ After decades of harmonisation efforts, cross-border commercial activities continued to be faced with significant divergences in national company laws.

Most importantly, a sizeable number of Member States continued to apply a rule of private international law which is known as the "real seat theory". According to this rule, a company's legal capacity is determined by ence to the law applicable in the place where its actal centre of administration, or head office, is established, as opposed to the "incorporation theory", by virtue of which legal capacity is determined in accordance wth the law of the State in which dhe company has been icorporated. The effect of the "real seat theory" is to exludea choice of law for entrepreneurs wishing to set up a company. If the centre of administration is a given factor in view of the business operations, the company must be formed in accordance with the company law that applies in the place of the company's centre of administration, or else it will not acquire the status of a legal person there. In contrast, the "incorporation theory" does not require any real connection of the company's business operations with the 'State of incorporation, permiting what is called "letter-box companies" on account

\footnotetext{
${ }^{1}$ Commentary on Art 8, note 2.

${ }^{2}$ Art 8(2) ACL states :"Where company's head office is located in the territory of the Republic of Albania, the company shall be subject to the present Law".

${ }^{3}$ Art 8 ACL states : "Unless the statute provide otherwise, a company's head office shall be the place where the major part of its business is carried out".

4 The only measure directed specifically at cross-border situations was the Eleventh Directive 89/666/EEC concering disclosure requiremets in respect of branches opened in a Member State by certain types of company governed by the law of another State.
} 
that the only presence of the company in the State of incorporation is a purely formal one, such as the ofice address of an attorney or a company formation agent.

In these circumstances, the European Court of Justice (ECJ) seized the initiative.

\subsection{Case \# 1 : Centros}

In 1999 the Court decided a case which is commonly known by the name of the company involved as the "Centros" case. ${ }^{1}$ In these case, two persons wanted to estabilish a business in Denmark in the legal form of a company imcorporated under dhe law of the United Kingdom (Greit Britain). Their declared purpose was to evade the Danish compamy law, which required a minimum subscribed capital for the formation of a private limited- liability company whereas English law permits the formation of such a company with only a notional subscribed capital, which can be as low as 1 pound. After registration in the United Kingdom, the company applied for the registration of a branch in Denmark. The Danish authorities refused to register the branch on the grounds, inter alia, that Centros did not trade in the United Kingdom and was in fact seeking to establish not a branch, but a principal establishment in Denmark, by circumventing the national Danish rules concerning the minimum capital. The EJC rejected that argument: the key passage of the dicision reads: "The facts that a national of a Member State who wishes to set up a company chooses to form it in the Member State whose rules of company law seem to him the least restrictive and to set up branches in other member States cannot, in itself, contitute an abuse of the right of establishment. The right to form a company in accordance with the law of a Member State and to set up branches in other Member States is inherent in the exercise, in a single market, of the freedom of establishment guaranteed by the Treaty."

\subsection{Case \# 2 : Überseering}

Not long after the "Centros" decision, a German court referred a case to the ECJ, known as "Überseering" (often found as "Überseering")2, The case featured a company, Überseering, which had been validly incorporate under dhe law of the Netherlend. In 1990 dhe company acquired a piece of land in Germany, and 1992 it hired another company (NCC) to refurbish a garage and a motel on the site. In 1994 all shares in Überseering were acquired by two German nationals, which resulted in the transfer of the company'center of administration to Germany. Subsequently, Überseering sued NCC for breach of contract, in German court, and the foundamental question arose whether, according to Germany law, which applied the real seat theory, Überseering was recognised as a legal person. Given that Überseering had originally been incorporate and continued to be registered in the Natherlands, German law would only recognize the company as a legal person as long as its centre of administration was in the Natherland, whereas the company lost its status as a legal person from the point of view of German law as soon as it transferred its centre of administration to Germany. The ECJ, however, found this result to be incompatible with the freedom of establishment guaranted by the EC-Treaty. Moreover, the ECJ held that Überseering, being validly incorporated in Natherlands was entitled to exercice its freedom of establishment in germany "as a company incorporated under Natherlands law" even after the acquisition of all its shares by German nationals residing in Germany, "since that has not caused Überseering, to cease to be a legal person under Natherlands law."

\section{Conclusion}

Albanian Company law has changed profoundly in recent time.

Given the objective to bring Albanian law in line with European Union requirements on company law, it is not a big surprise that the legislator assisted by international experts essentially decided to design a new company law "from scratch" rather than modifying the existing Albanian legal framework. After all, the previously on companies followed a very different approach than most of the Member States'systems which served as the basis for the Community legislation in this area.

The Albanian Company Law was drafted so as to implement (with limited exceptions) the Europian company law standards (the so called "acquis") and thereby to fulfil Art 70 of the Stabilisation and Association Agreement between Albania and the Europian Union, which aims at full approximation to the acquis communautaire.

\footnotetext{
1 Full reference : EC 9.3.1999, C-212/97, Cetros Ltd vs Erhverus-og elskabsstyrelsen, European Court Reports 1999

2 ECJ 5.11.2002, C-208/00 Überseering BV vs NCC Nordic Construction Company Baumanagement GmbH, European Court Reports 2002.
} 
As it has been the aim of legislator to implement European law, provisions of the Companies Law which are derived from a Europian source should be interpreted according to the "word and spirit" of the relevant European harmonisation measure.

For matters not regulated by Europian Law, the new Albanian Companies Law relies heavily on inspiration from the company laws of Germany and England. Accordingly, guidance on the interpretation of the law may also come from the courts of a Member State if the provision in question was taken from the corresponding Member State Law.

This new departure brings in its wake a profound need for information among lawyers, judges and other members of the legal professions. Currently, there are few materials one can turn to when interepreting the new company law.

Most importantly, a sizeable number of Member States continued to apply a rule of private international law which is known as the "real seat theory". According to this rule, a company's legal capacity is determined by ence to the law applicable in the place where its actal centre of administration, or head office, is established, as opposed to the "incorporation theory", by virtue of which legal capacity is determined in accordance wth the law of the State in which dhe company has been icorporated. The effect of the "real seat theory" is to exludea choice of law for entrepreneurs wishing to set up a company. If the centre of administration is a given factor in view of the business operations, the company must be formed in accordance with the company law that applies in the place of the company's centre of administration, or else it will not acquire the status of a legal person there. In contrast, the "incorporation theory" does not require any real connection of the company's business operations with the 'State of incorporation, permiting what is called "letter-box companies" on account that the only presence of the company in the State of incorporation is a purely formal one, such as the ofice address of an attorney or a company formation agent. In these circumstances, the European Court of Justice (ECJ) seized the initiative.

\section{Bibliography}

[1] Albanian Compani Law No.9901

[2] Commentary of the new Companies Law, 2009.

[3] Dr. Argita Malltezi. 2010. Scientific Legal Magazine (The School of Magistrates), "Corporate Governance",

[4] Dr. Martin Winner \& Magistrat Edmund - Filippe Schuster. 2010. Scientific Legal Magazine (The School of Magistrates), "Some Remarks on the New law on enterpreneurs and companies".

[5] International Finance Corporation IFC (World Bank Group). 2009. "Corporate Governance"

[6] Stabilisation and Association Agreement between Albania and the Europian Union, Art. 70.

[7] The case law of the judicial practice of the European Court of Justice. 